\title{
EXPERIMENTAL INVESTIGATION AND CFD SIMULATION OF INDOOR AIR QUALITY IN ROOM USING IMPINGING JET VENTILATION SYSTEM AT DIFFERENT OCCUPANT DISTRIBUTION
}

\author{
Ala'a Abbas Mahdi \\ alaa.mahdi1959@gmail.com
}

\author{
Sara Mohammed Abbas
}

alifahem1988@gmail.com

1,2 University of Babylon, Iraq - College of engineering-Department of Mechanical Engineering

\begin{abstract}
The current paper reports the analysis and design of air quality and human thermal comfort in rooms using impinging jet ventilation system at different occupant distribution. Theoretical and experimental studies at different situations of occupant distribution used the square cross sectional supply air duct with height from the foot level end $(0.1 \mathrm{~h})$. This work presents a numerical study for predicting the indoor airflow and temperature distribution by adopting impinging jet ventilation system in office room. The emergence of the three zones flow field of an impinging jet is mostly divided into three distinguished zones: impingement zone, wall jet zone and free jet zone which produce excessive kinetic energy at the stagnation zone and distribute approximately in the longitudinal and lateral directions over the floor. Acceptable Air Distribution Performance Index (ADPI), effective temperature and ventilation efficiency were found at situations of occupant distribution (when the occupant located at the center of the room one sitting in front of the other gives optimum human thermal comfort if compared with the other situations of occupant distributions).
\end{abstract}

Keywords: Impinging jet ventilation, Numerical simulation, Indoor air quality (IAQ), occupant distribution

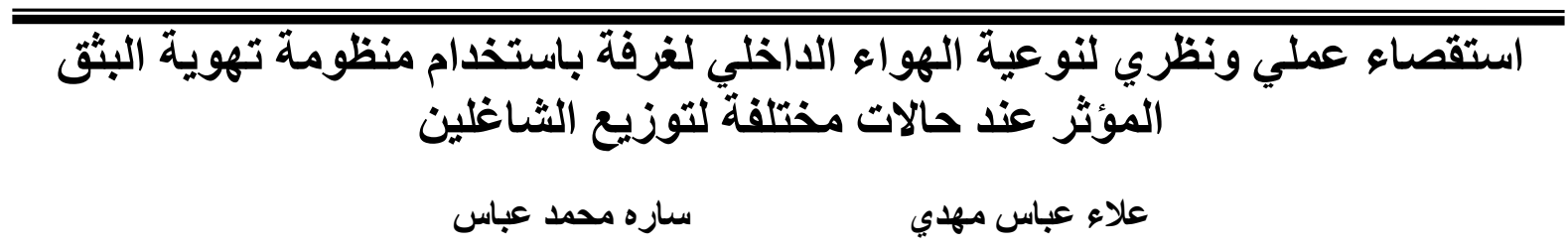

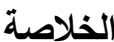

تم دراسة منظومة تهوية البثق المؤثر كتهوية استر اتيجية جديدة لاستخدامها في المباني الصناعية و المكاتب. حيث يشير

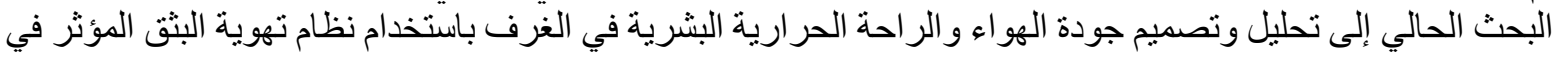

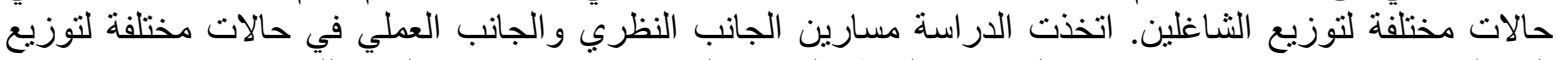

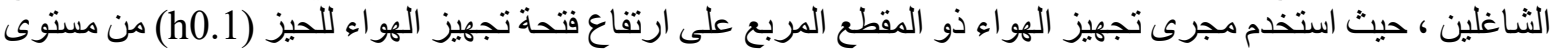

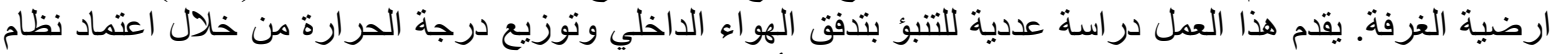

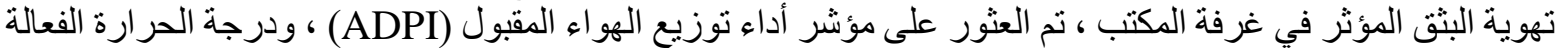
وكفاءة التهوية في الحالة الثانية لتوزيع الثاغلين (و عندما يكون توزيع الثاغلين بوضعية الجلوس المتقابل في وسط الغرفة

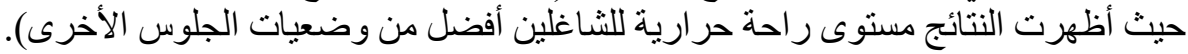




\section{NOMENCLTURE}

Symbols

$\mathrm{A}_{\mathrm{f}}$

$\mathrm{A}_{\mathrm{s}}$

$\mathrm{Cp}$

dx dy dz

$\mathrm{E}_{\mathrm{ij}}$

g

$\mathrm{K}_{\mathrm{i}, \mathrm{j}, \mathrm{k}}$

$\mathrm{P}$

$\mathrm{Pz}$

QDV

$\mathrm{q}_{\mathrm{i}}$

$\mathrm{Q}_{\mathrm{oe}}$

$\mathrm{Q}_{\mathrm{oz}}$

$\mathrm{R}_{\mathrm{A}}$

$\mathrm{Rp}$

$\mathrm{S}$

$\mathrm{T}_{\mathrm{av}}$

$\mathrm{T}_{\mathrm{i}, \mathrm{j}, \mathrm{k}}$

$\Delta \mathrm{Th}_{\mathrm{f}}$

$\mathrm{T}_{\mathrm{sp}}$

$\mathrm{U}_{\mathrm{s}}$

$\mathrm{U}_{\mathrm{x}}$

\section{Abbreviations}

ASHRAE

$\mathrm{ACH}$

CFD

IAQ

RNG

IJV

MV

DV

\section{Sub-Scripts}

av.

f

$\mathrm{h}$

1

\section{$\underline{\text { Greek letters }}$}

\section{$\rho$}

$\varepsilon$

$\sigma$

$\omega$

$\Gamma$
Description

Surface area for floor

Face area for diffuser

Specific heat of the air at constant pressure.

Control volume

The mean rate of deformation tenser

Gravitational acceleration

Turbulent kinetic energy at cell $(\mathrm{i}, \mathrm{j}, \mathrm{k})$

Pressure

Person per unit area

Air required to satisfy the sensible cooling load in a DV system

Cooling load for the overhead lighting

Cooling load for occupants, desk lamps and equipment.

Fresh air flow rate

Outdoor air flow rate required per unit area

Outdoor air flow rate required per person

Source term for the rate of thermal energy production

average room temperature

Temperature at cell $(\mathrm{i}, \mathrm{j}, \mathrm{k})$

Temperature difference from head to foot level.

Setup (design) temperature.

Supply air velocity

Local air velocity

American Society for Heating Refrigeration and Air Conditioning Engineer

Air Change per Hour

Computational Fluid Dynamics

Indoor Air Quality

Re-Normalization Group

Impinging Jet Ventilation

Mixing Ventilation

Displacement Ventilation

Average

Floor

Room height

Overhead light

Air density

Turbulent energy dissipation rate.

Prandtl or Schmidt number

Specific dissipation rate

Diffusion coefficient (diffusivity) 


\section{INTRODUCTION}

Impinging Jet Ventilation (IJV) is the air with high momentum can be discharged downwards, hits the ground and spreads along its length, thus creating fresh air in the form of a very thin shear layer along the ground, "this method can the air jet to beat the buoyancy force produced from heat provenances and reach more areas" H.J. Chen, B. Moshfegh , M. Cehlin (2011), Huijuan Chen, Bahram Moshfegh, Mathias Cehlina(2013), the impingement of a turbulent jet has been widely studied on a flat panel (wall) with different arrangements. In all early investigations, the momentum flow prediction follows the same procedures as in the traditional border layer. The impinging jet is significant because of its different flow areas is considered an interesting test situation (ie, potential core area, free jet area, flow or flow deflection area, and jet-wall area). Early and modern investigators also studied the phenomenon of free and turbulent jet, Beltaos and Rajaratnam (1973), detailed results were provided on the collision zone and the expansion of the results that were available in the free jet areas and the jet wall, T. Karimipanah, H.B. Awbi (2001). An experimental study are present of the turbulent structure on the midline of two jet planes was provided. They pointed out that the collision of the aircraft is not affected by the presence of a plate more than $75 \%$ of the distance between the nozzle and the panel and also the troubled 1 of the change of the jet from the level of balance near the collision area. A counter plane is somewhat similar to the flow of a recession whose infinite stream runs on a limited body, Lee $\mathrm{K}$, Xue GQ, JIANG Z, Chen QY(2012). The investigated impinging jet configuration is shown in Figure(1), Huijuan Chen (2014), since the flow field is sub-divided into three areas: (i) Free jet region, (ii) impinging region and (iii) wall jet region, between these areas there are also transitional areas. Numerical analysis and the development of impinging flows have received considerable attention. However, the result of the analyses may depend on the model of the disorder utilized. The plane will approach the plate at some distance from the plate to begin to "feel" a plate, Lee K, Xue GQ, JIANG Z, Chen QY(2012). The distance from the plate where the midline starts the velocity deviation from the free plane curve is taken as the end of the free plane area and the start of the impingement area. From Figure (1). Feel the effect of the panel when the distance of the plate $<0.14 \mathrm{~h}$, which is consistent with the results obtained, Varodoumpun J, Navvab M(2007). The impinging jet ventilation (IJV) system was proposed and developed to combine the advantages of mixing ventilation (MV) and displacement ventilation (DV) systems studied different air distribution systems in a full-size classroom with realistic heat loads. Considering air exchange efficiency and mean age of air, the IJV system performed very similar to the DV system and much better than the MV system. In designing the impinging jet ventilation system, its various operating parameters should be optimized to enhance the thermal comfort and the IAQ while consuming a reasonable amount of energy Samira Haghshenaskashani1, Behrang Sajadi1, Mathias Cehlin (2018). Only a few studies have been conducted using statistical optimization methods in the field of thermal comfort and energy performance of ventilation systems, e.g. the response surface method (RSM) and Taguchi method. The Taguchi method was widely used in many engineering applications to provide the optimal design parameters based on the specified constraints. In order to understand the relationship between the independent variables and the objective functions, a large number of tests are usually needed, which leads to tremendously timeconsuming and costly research work. As a result, CFD investigations have gained popularity in the HVAC industry in the recent decades. Several attempts have been made to use optimization methods in building energy estimation and building system performance analysis Behrang Sajadi1, Mathias Cehlin (2018). The main objectives of the current work is to arrive understanding of the implementation of the principle of jet ventilation to provide a good 
office climate by using Computational Fluid Dynamics (CFD) as well as system performance with respect to effectiveness and thermal comfort ventilation under the Iraqi climate.

\section{TEST ROOM SETUP}

\section{Test room equipment}

A set of full-scale office room experiment were conducted to study the airflow, temperature transport with the IJV system at different situations of occupant distribution. The tested room delivered and setup by all the necessary equipment's for IJV system as shown in Figure (2).

\section{Rooms' configuration}

Office room experiments were adopted on a full scale to study temperature distribution and velocity magnitude using IJV system under Iraqi climate conditions by using square cross sectional supply area of supply air duct at different situations of occupant distribution. The test office room dimensions are (length $\mathrm{x}$ width $\mathrm{x}$ height $)(3 \times 1.75 \times 3) \mathrm{m}$, which is furnished for two persons simulator (shape of human body properties represented by using manikin. The assumed elevation of human manikin is $(1.1 \mathrm{~m})$ for a person at sitting situation, with heat source of $(75 \mathrm{~W})$ placed inside manikin to generate amount of heat from human body as shown in Figure (3). , having releasing heat similar to a human and the same surface area, two PC-simulator, two tables, one lamp were placed as a heat source, the exhaust grille located under the ceiling on the north side wall, one door located at west side Also front view and top view for experimental tested room shown in Figure (4). and the cooled air delivered by using an air conditioner unit of cooling capacity of $(7.0344 \mathrm{~kW})$.

\section{AIR HANDLING AND SUPPLY SYSTEM}

There are two steps, Procedures are based on results of ASHRAE research, Project-949.

\section{Step one: Supply flow rate}

\section{Calculation of the cooling load ventilation air flow rate, QIJv:}

The amount of air flow rate air needed for ventilated room can be determined from equation (1), Chen, Q., Glicksman, L.R., Yuan, X., Hu, S., \& Yang, X(1999).

$\mathrm{Q}_{\text {IJV }}=\left(0.295 \mathrm{q}_{\mathrm{oe}}+0.132 \mathrm{q}_{1}+0.185 \mathrm{q}_{\mathrm{ex}}\right) /\left(\rho \mathrm{c}_{\mathrm{p}} \Delta \mathrm{T}_{\mathrm{hf}}\right)$

All heat transported through walls and windows to room should be taken in to account when calculating external heat gain $\left(\mathrm{q}_{\mathrm{ex}}\right)$ using the equation (2).

$\mathrm{Q}=\mathrm{U} * \mathrm{~A} *\left(\mathrm{~T}_{\mathrm{o}}-\mathrm{T}_{\mathrm{sp}}\right)$

$\mathrm{U}=1 / \mathrm{R}_{\mathrm{th}}$

$$
\mathrm{R}_{\mathrm{th}}=\frac{1}{\mathrm{~h}_{\mathrm{i}}}+\frac{\mathrm{x}_{1}}{\mathrm{k}_{1}}+\ldots \ldots+\frac{\mathrm{x}_{\mathrm{n}}}{\mathrm{k}_{\mathrm{n}}}+\frac{1}{\mathrm{~h}_{\mathrm{o}}}
$$

\section{Calculation of fresh air flow rate, Qoz:}

From ASHRAE Standards 62.1-2004, ASHRAE. Standard (2004). Equation (5) is used to determine the flow rate of fresh air.

$\mathrm{Q}_{\mathrm{oz}}=\frac{\mathrm{R}_{\mathrm{p}} \mathrm{P}_{\mathrm{z}}+\mathrm{R}_{\mathrm{A}} \mathrm{A}_{\mathrm{f}}}{\mathrm{E}_{\mathrm{z}}}$

The values of $\left(\mathrm{R}_{\mathrm{p}}, \mathrm{R}_{\mathrm{A}}, \mathrm{P}_{\mathrm{z}}\right.$ and $\mathrm{E}_{\mathrm{z}}$ ) determined from (ASHRAE standards 62.1-2004) [12]. Then, choose the large value of flowrate calculated from (a\&b) as the design flow rate of the supply air: 


\section{Step two: Supply air temperature:}

Equation (6) used to determine the supply air temperature $\left(\mathrm{T}_{\mathrm{s}}\right)$ for displacement ventilation applications, Chen, Q. \& Glicksman(2003).

$\mathrm{T}_{\mathrm{s}}=\mathrm{T}_{\mathrm{sp}}-\Delta \mathrm{T}_{\mathrm{hf}}-\left[\left(\mathrm{A}_{\mathrm{f}} . \mathrm{q}_{\mathrm{t}}\right) /\left(0.584 \mathrm{Q}_{\text {IJv }^{2}}+1.208 \mathrm{~A}_{\mathrm{f}}\right.\right.$. $\left.\left.\mathrm{Q}_{\text {IJV }}\right)\right]$

Eq. (7) was used to predict total heat transfer rate during the experiments

$\mathrm{q}_{\mathrm{t}}=\mathrm{q}_{\mathrm{oe}}+\mathrm{q}_{1}$

Then to determine air flow rate and supply temperature applied the following values, Iraqi cooling code, (2012).

$\begin{array}{cccc}\text { qperson } & \mathbf{q}_{\text {computer }} & \mathbf{T}_{\text {sp }} & \Delta \mathbf{T}_{\mathbf{h f}} \\ 75 \mathrm{~W} & 45 \mathrm{~W} & 24^{\circ} \mathrm{C} & 2{ }^{\circ} \mathrm{C}\end{array}$

Values of air flowrate $\left(\mathrm{Q}_{\mathrm{s}}\right)$ and air supply temperature $\left(\mathrm{T}_{\mathrm{s}}\right)$ can be determined and listed in Table1. The air change per hour (ACH) calculated by using Eq. (8), H. B. Awbi, Ventilation of Buildings, Spon Press, second edition, (2003).

$\mathrm{ACH}=\left(\mathrm{Q}_{\mathrm{S}} / \mathrm{V}_{\mathrm{Room}}\right) * 3600$

\section{Selection of Supply Duct}

In impinging jet ventilation there are some goals must be investigated the temperature fields, airflow ventilation effectiveness, as well as thermal comfort with respect to air exchange efficiency and heat removal effectiveness of the impinging jet ventilation system for an office climate.

For the square cross sectional area of supply air duct used in present work at $0.1 \mathrm{~h}$ opening height from the foot level the supply air velocity $2.5 \mathrm{~m} / \mathrm{s}$. Then Eq (9) is used to calculate cross sectional area for each air duct, Huijuan Chen (2014).

$\mathrm{Q}_{\mathrm{s}}=\mathrm{u}_{\mathrm{x}} * \mathrm{~A}_{\mathrm{s}}$

The dimensions of supply air duct for all types are listed in Table 2.

\section{MEASUREMENTS PROCEDURES}

Measuring of airflow field velocity and temperature distribution were recorded in the test room on three poles. Each pole has six nods being placed at different altitude levels of $(0,0.4$, $0.8,1.1,1.4 \& 1.8) \mathrm{m}$ from the foot level. The initial pole used to register parameters which is located at $(\mathrm{x}=2, \mathrm{y}=0, \mathrm{z}=0.875) \mathrm{m}$ from the zero source point. The second pole is located at $(\mathrm{x}=0.7, \mathrm{y}=0, \mathrm{z}=0.5) \mathrm{m}$ from the zero source point, while the third pole located at $(\mathrm{x}=0.7, \mathrm{y}=0$, $\mathrm{z}=1.25) \mathrm{m}$ from the zero source point. A sensor measured the temperature on each point of these poles. Also, at pole number one a measurement device is used to record air velocity at terminal of supply air duct and relative humidity at breathing zone $(1.1 \mathrm{~m})$ near the supply air outlet. This device used to check the air velocity at the terminal of supply air duct which is equal $2.5 \mathrm{~m} / \mathrm{s}$ and recorded the related humidity equal $42 \%$. To measure the air temperature distributions inside the tested room, three vertical poles was shown in Figure (5), considered as. In order to register the air temperature a twenty four number of thermocouples type $\mathrm{K}$ were used, in the empirical work temperature logger of 12 channels with universal thermocouple was used. To record the value from the thermocouples all thermocouples are connected to a computer which is controlled by a data acquisition (BTM-4208SD) as shown in Figure (6). 


\section{EXPERIMENTAL READINGS}

The experimental readings were recorded in May (2017) at steady state time (14:00 p.m.) as listed in Table 3. The readings recorded after reach steady state conditions and repeating each reading three times to get accurate results. During the measurements, it should be noted that the change in ambient conditions was ignored when the same ventilation type was measured .The reason of this in order to enable us to compare each case study for ventilation under the same conditions. The following main steps of experimental work are considered:

1.The outdoor and indoor conditions data were recorded before starting the impinging jet ventilation system.

2.The cooling air supply system was left in operating case and controlled until reach indoor steady state temperature equal to $\left(24^{\circ} \mathrm{C}\right)$.

3.The readings of air parameters were taken after two to three hours of operating the I.J. ventilated system.

4.Experimental readings were recorded for all situations of occupant distribution for measuring the flow field temperature, velocity and indoor air quality.

\section{COMPUTATIONAL SET-UP AND NUMERICAL SCHEME}

\section{Physical model and boundary conditions}

Numerical results were adopted in the current study of the chamber tested using many calculations at various planes and all fields as illustrated in Figure (7), with details presented in table 4. A test room furnished like a two-person office is the physical model under seeing, with the dimensions $(3 \times 1.75 \times 3) \mathrm{m}$. various components are used to simulate the summer working climate and the airflow rate is $(34.825 \mathrm{l} / \mathrm{s})$ and the air supply temperature is $(20.08$ $\left.{ }^{\circ} \mathrm{C}\right)$, a turbulence intensity of $(5 \%)$, i.e. two PC-simulator $(90 \mathrm{~W})$, two manikin $(80 \mathrm{~W})$, lighting $(100 \mathrm{~W})$, heated floor $(150 \mathrm{~W})$, the exhaust opening and IJ device and are composite on the same of aspect wall. The modeled room was shown in Fig. 8. The solution to a flow field problems (velocity, temperature, pressure, etc.) is defined at nodes for all cell. The accuracy of CFD solution is governed by the number of cell in the grid. In general the better the solution accuracy, the larger the number of cell. Both the cost of solution and its accuracy in term of necessary computer hardware and calculation time. Figure ( 9 and 11)., show part of the meshed model for different situation of occupant distribution. The "air distribution performance point (ADPI) is the percentage determined by the number of measured points in an occupied area where the limit is within the specified limits $\left(>1.7^{\circ} \mathrm{C}\right.$ and $\left.<1.1^{\circ} \mathrm{C}\right)$ on the total number of measured points, Chen, Q. \& Glicksman(2003). A literature index of between 60 and 69 is unsatisfactory, 70 to 79 satisfactory and 80 and above as a good distribution of air. Generally ADPI of 80 is considered acceptable.

\section{Boundary conditions}

The boundary conditions are specified as follows: The working fluid used is air and the flow assumed to be three-dimensional, steady, Newtonian, incompressible fluid and turbulent flow. And meshed case study depending on many testing meshes then analyses by using Ansys Fluent 15 code software until the residual error for solved equations arrived to $\left(10^{-3}\right)$ and $\left(10^{-6}\right)$ for energy equation. Second-order upwind scheme using for the convection terms. PRESTO (Pressure Staggering Option) scheme is used for the pressure.For the pressure-velocity coupling the SIMPLEC scheme is used. When working with unstructured meshes, a highorder scheme is preferred for the discretization of convection terms to minimize the discretization errors. In order to investigate species chemical distribution, an additional variable introduced to the main fluid of air in the CFD model. Ventilation efficiency of IJV is assessed with regards to heat removal effectiveness, and air exchange efficiency based on 
mean age of air calculated by CFD. Mixture of air and $\mathrm{H}_{2} \mathrm{O}$ was treated identically as air at normal atmospheric pressure. The flow was assumed to be steady, three-dimensional flow, Newtonian, incompressible fluid, no chemical reaction, and turbulent flow.

\section{GOVERNING EQUATIONS}

The working used fluid is air and the flow assumed to be three-dimensional flow, steady, Newtonian and incompressible fluid and turbulent flow. The governing equations of motion based on Navier-Stockes equations conservation form for continuity, momentum and energy equations as follows, Chen, Q., Glicksman, L.R., Yuan, X., Hu, S., \& Yang, X.(1999).

$$
\begin{aligned}
& \frac{\partial}{\partial x}(\rho u)+\frac{\partial}{\partial y}(\rho v)+\frac{\partial}{\partial z}(\rho w)=0 \\
& \frac{\partial}{\partial x}(\rho U U)+\frac{\partial}{\partial y}(\rho U V)+\frac{\partial}{\partial z}(\rho U W)=-\frac{\partial p}{\partial x}+\frac{\partial}{\partial x}\left(\mu \frac{\partial U}{\partial x}\right)+\frac{\partial}{\partial y}\left(\mu \frac{\partial U}{\partial y}\right)+\frac{\partial}{\partial z}\left(\mu \frac{\partial U}{\partial z}\right) \\
& +\frac{1}{3} \frac{\partial}{\partial x}\left[\mu\left(\frac{\partial U}{\partial x}+\frac{\partial V}{\partial y}+\frac{\partial W}{\partial z}\right]+\rho g_{x}\right. \\
& \frac{\partial}{\partial x}(\rho U V)+\frac{\partial}{\partial y}(\rho V V)+\frac{\partial}{\partial z}(\rho V W)=-\frac{\partial p}{\partial y}+\frac{\partial}{\partial x}\left(\mu \frac{\partial V}{\partial x}\right)+\frac{\partial}{\partial y}\left(\mu \frac{\partial V}{\partial y}\right)+\frac{\partial}{\partial z}\left(\mu \frac{\partial V}{\partial z}\right) \\
& +\frac{1}{3} \frac{\partial}{\partial y}\left[\mu\left(\frac{\partial U}{\partial x}+\frac{\partial V}{\partial y}+\frac{\partial W}{\partial z}\right]+\rho g_{y}\right. \\
& \frac{\partial}{\partial x}(\rho U W)+\frac{\partial}{\partial y}(\rho V W)+\frac{\partial}{\partial z}(\rho W W)=-\frac{\partial p}{\partial z}+\frac{\partial}{\partial x}\left(\mu \frac{\partial W}{\partial x}\right)+\frac{\partial}{\partial y}\left(\mu \frac{\partial W}{\partial y}\right)+\frac{\partial}{\partial z}\left(\mu \frac{\partial W}{\partial z}\right)+ \\
& \frac{1}{3} \frac{\partial}{\partial z}\left[\mu\left(\frac{\partial U}{\partial x}+\frac{\partial V}{\partial y}+\frac{\partial W}{\partial z}\right]+\rho g_{z}\right. \\
& \frac{\partial}{\partial x}(\rho U T)+\frac{\partial}{\partial y}(\rho V T)+\frac{\partial}{\partial z}(\rho W T)=\frac{\partial}{\partial x}\left(\Gamma \frac{\partial T}{\partial x}\right)+\frac{\partial}{\partial y}\left(\Gamma \frac{\partial T}{\partial y}\right)+\frac{\partial}{\partial z}\left(\Gamma \frac{\partial T}{\partial z}\right)
\end{aligned}
$$

\section{TURBULENCE MODEL}

RNG K- $\varepsilon$ turbulence model is used with the following equations, FLUENT Inc. FLUENT 6.3.26 user's guide, (2006).

\section{RNG K- $\boldsymbol{\varepsilon}$ model}

$$
\begin{aligned}
& \rho U_{i} \frac{\partial k}{\partial x_{i}}=\mu_{t} S^{2}+\frac{\partial}{\partial x_{i}}\left[\alpha_{k} \mu_{e f f} \frac{\partial k}{\partial x_{i}}\right]-\rho \varepsilon \\
& \rho U_{i} \frac{\partial \varepsilon}{\partial x_{i}}=C_{1 \varepsilon}\left(\frac{\varepsilon}{k}\right) \mu_{t} S^{2}+\frac{\partial}{\partial x_{i}}\left[\alpha_{k} \mu_{e f f} \frac{\partial k}{\partial x_{i}}\right]-C_{2 \varepsilon} \rho\left(\frac{\varepsilon^{2}}{k}\right)-R
\end{aligned}
$$

The values of model constants are: $C_{1 \varepsilon}=1.42$ and $C_{2 \varepsilon}=1.68$ respectively.

\section{RESULTS AND DISCUSSION}

To validate the CFD model, the simulated results of IJV compared with experimental results at different situation of occupant distribution. At pole- 1 the simulated temperature distribution compared with the experimental measurements as shown in Figure (15 and 17). The predicted 
air temperatures have some deviation with the experimental results, which clearly showed the difference in the temperature curves.

Mean deviation between experimental and numerical rate of the three situations of occupant distribution gives more acceptable agreement of $9 \%, 6 \%$ and $12 \%$ respectively. Figure (18 and 19) display numerically the contours of air temperature distribution in the non-isothermal tested room that the temperature increases from $18{ }^{\circ} \mathrm{C}$ closely at the supply air terminal and reach about $30^{\circ} \mathrm{C}$ near the human body and (pc) simulater. The air cold are expanded over the floor of the room and then passes vertically as a hot air due to heat exchange with heat sources in the room (occupants \& computers). Thermal plumes are generated by convection due to the differences in temperature between the heat sources and the surrounding air. Also, it was found that the floor area near the distribution area of the display will show the lowest temperatures, due to the cooling influence of the supply enters the air. In addition, a gradual raise in temperature gained with the increase of height within the chamber. Also, a rise in indoor temperature can be observed near the person, PC-simulator and lighting, and note the emergence of the three areas the flow field of an impinging jet is generally divided into three distinct areas: free jet area, impingement area and wall jet area as show in Figure (19). Excessive kinetic energy is produced in the recessive zone and distribute approximately in the longitudinal and lateral directions over the floor. Acceptable Air Distribution Performance Index (ADPI) and effective temperature, and ventilation efficiency was found at $2^{\text {nd }}$ O.D. of the other gives optimum human thermal comfort if compared with the other situations of occupant distributions as shown in Table 5. Also a good air distribution system not only participate to energy keeping, but also promotes a convenient and healthy climate for residents as show in Figure (20). Figure (21). Presents streamlines flow patterns from the square supply air IJV duct for case of outlet height $0.1 \mathrm{~h}$ from foot level and for all situations of occupant distribution. Under the roof, the air moves in a general direction towards the wall of the air intake, driven by the buoyancy forces of the heat column. Due to the buoyancy effects of indoor heat sources (eg, occupant), the flow tends to be directed across the other side of the room. Near the corner between the walls of the entrance and the back. This downward flow integrate with the initial flows at the bottom of the chamber and thus increases the momentum of the penetration flow in the chamber, which leads to dropping the longer flow into the chamber as well as higher velocity in some positions. Figure (22 and 23) illustrate the air velocity vector field around the simulated occupant. A buoyancy-driven thermal plume develops in the vicinity of the body because of the temperature gradient between ambient air and the body surface and show air velocity vector for vertical plane at $\mathrm{Z}=0.875 \mathrm{~m}$. The predicted velocity vector was plotted at the surfaces $0.05 \mathrm{~m}$ away from the inlet wall, side wall and floor and horizontal plane at $\mathrm{Y}=0.1 \mathrm{~m}$ from the floor for all situations. The air moves horizontally on the ground due to the momentum of the air outlet supply and suction of the thermal columns. Then passes vertically to a high level in the room where it is exhausted from the exhaust grills. The movement of vertical air between layers is caused by convection forces associated with heat sources (occupant \& computer).

\section{CONCLUSIONS}

The present study focuses on assessment of square cross sectional area of supply air duct by using impinging jet ventilation system for predicting numerically and experimentally the airflow field and air temperature distribution under Iraqi climate at different situations of occupant distribution. The following conclusions have been listed from the results of the study:

1- Assessment of square cross sectional supply air duct in impinging jet ventilation system at opening terminal of $0.1 \mathrm{~h}$ at different situations of occupant distribution 
found at 2nd O.D. situations of occupant distributions gives more acceptable agreement a good air distribution system not only participate to energy keeping, but also promotes a convenient and healthy climate for residents, gives a more nearest to the standard Iraqi Cooling code in a theoretical analyses study for office room.

2- Acceptable Air Distribution Performance Index (ADPI), effective temperature, and ventilation efficiency was found at 2nd O.D. situations of occupant distributions (When the occupant located at the center of the room one sitting in front of the other gives optimum human thermal comfort if compared with the other situations of occupant distributions) and gives more acceptable agreement in terms of indoor air quality and human thermal comfort.

3- When the occupant located at the center of the room one sitting in front of the other gives optimum human thermal comfort if it compared with the other situations of occupant distributions.

4- Results from present study show that impinging jet ventilation system is efficient in the Summer of Iraq.

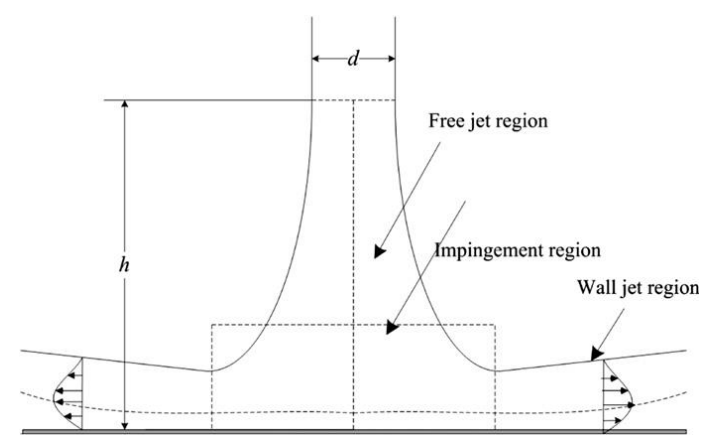

Fig. (1): Flow areas of an impinging jet

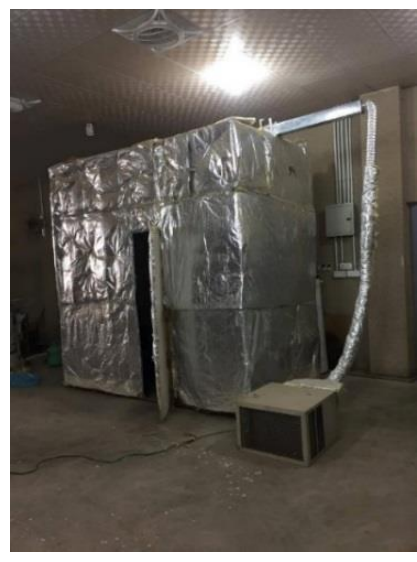

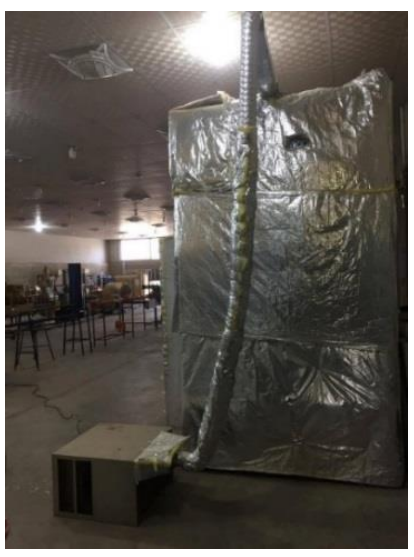

$\mathrm{b}$

Figure (2): Photograph of the (a) experimental isothermal tested room (b) air conditioner unit with supply air duct. 

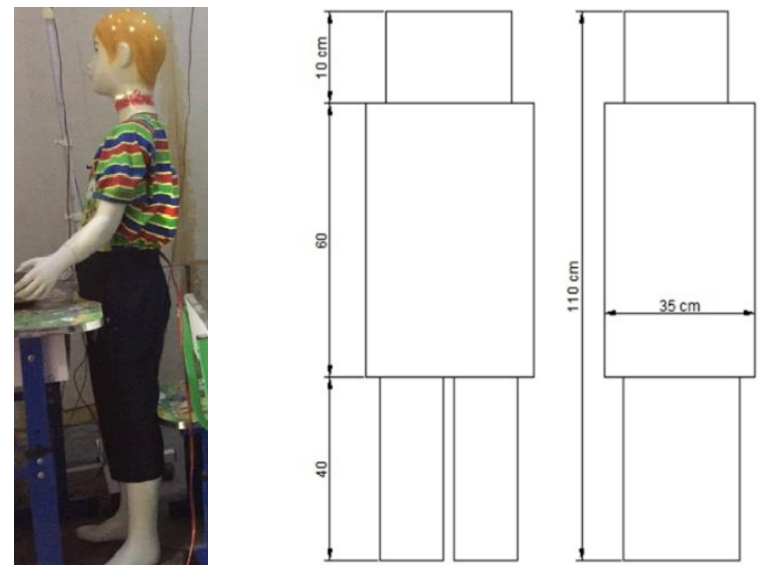

a- photograph

b- front view

c- side view

Figure (3): Thermal manikin used in the experimental work.

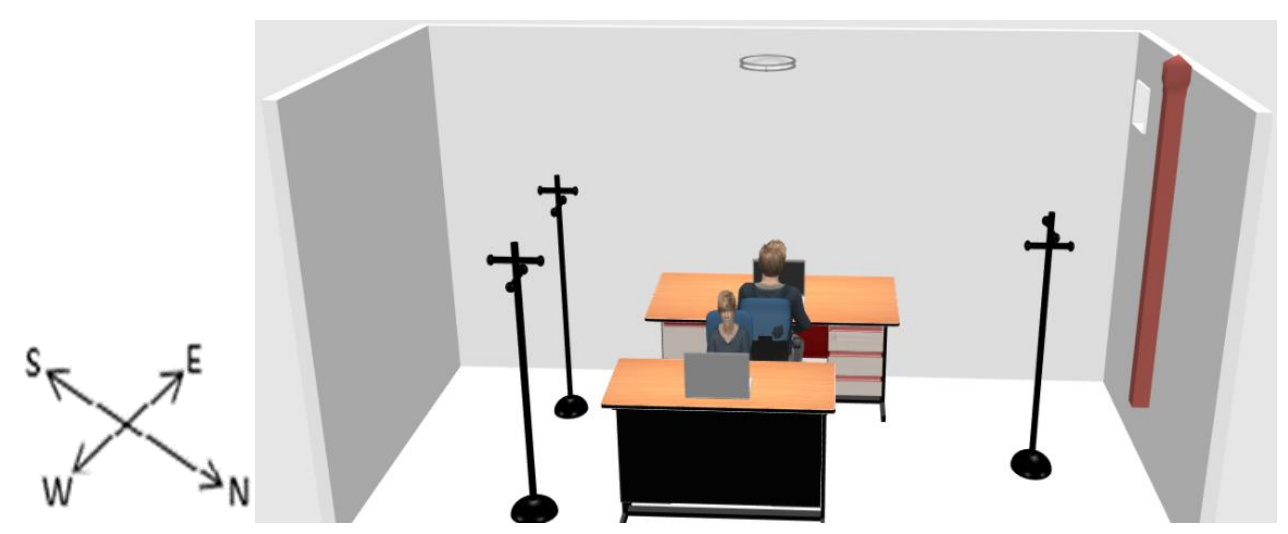

Figure (4): Schematic drawing of the office room.

Table 1. Values of air flow rate $\left(Q_{s}\right)$, supply air temperature $\left(T_{s}\right)$ and air change per hour $(A C H)$.

\begin{tabular}{|l|l|l|}
\hline $\mathrm{Q}_{\mathrm{s}}(\mathrm{l} / \mathrm{s})$ & $\mathrm{T}_{\mathrm{s}}\left({ }^{\circ} \mathrm{C}\right)$ & $\mathrm{ACH}$ \\
\hline 34.83 & 20.08 & 7.96 \\
\hline
\end{tabular}

Table 2. Dimensions of supply air duct

\begin{tabular}{|c|c|}
\hline Supply air duct & Square air duct \\
\hline $\begin{array}{c}\text { Cross sectional area } \\
\mathrm{m}^{2}\end{array}$ & 0.0144 \\
\hline $\begin{array}{c}\text { Duct length } \\
\mathrm{m}\end{array}$ & 2.7 \\
\hline
\end{tabular}



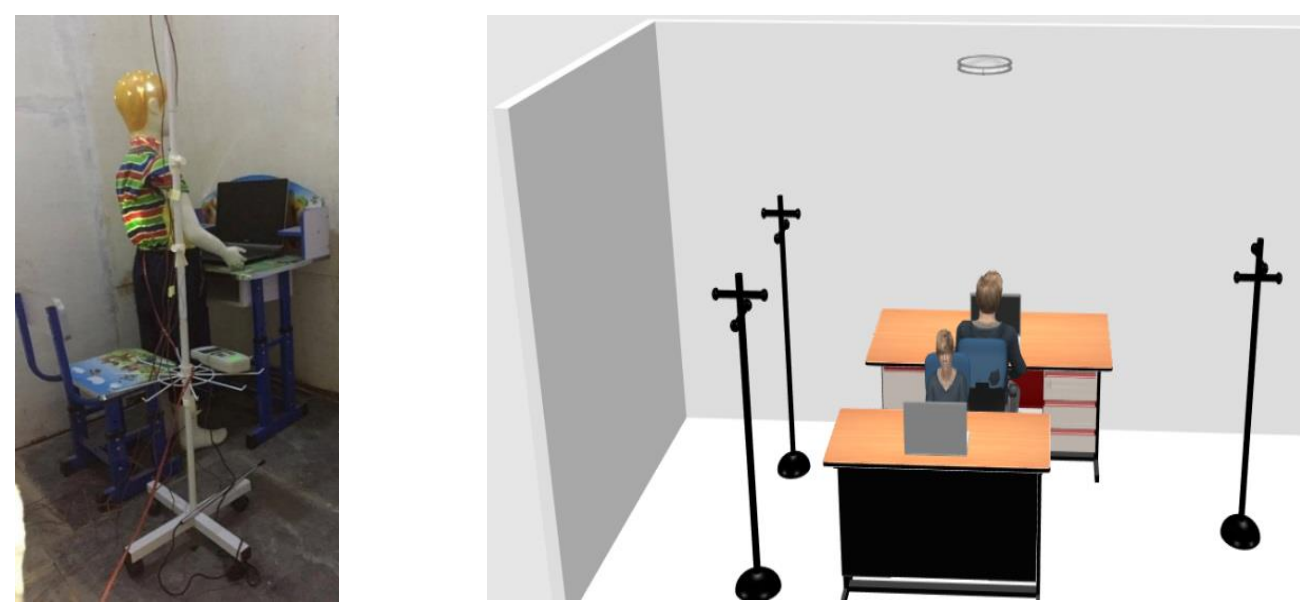

a

b

Figure (5): Layout of a pole for different measurements Schematic diagram of pole, (b) Photograph of pole location.

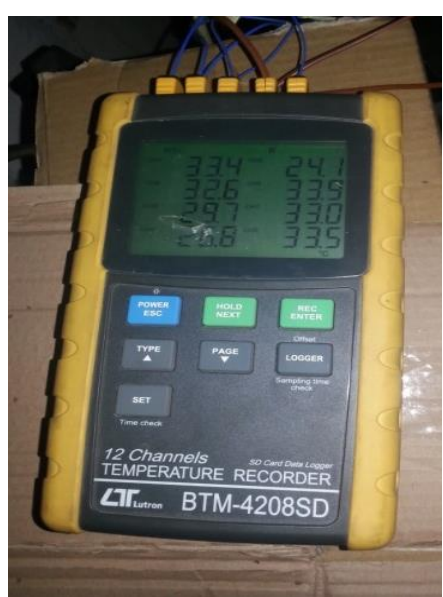

a

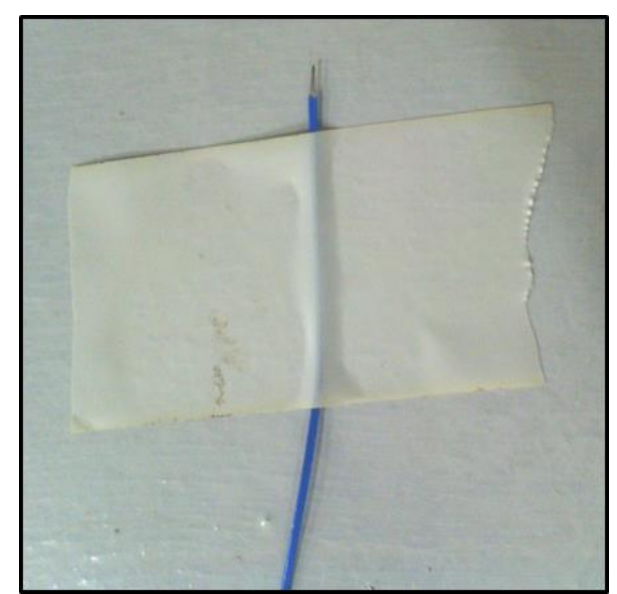

b

Figure (6): Surface temperature measurement system a- Temperature recorder b- Thermocouple attached to wall surfaces.

Table 3. Experimental results obtained by adopting IJV System

\begin{tabular}{|c|c|c|c|c|c|c|c|c|c|}
\hline \multirow{3}{*}{$\begin{array}{l}\text { Type of } \\
\text { supply air } \\
\text { duct }\end{array}$} & \multirow{3}{*}{$\begin{array}{l}\text { Opening } \\
\text { height from } \\
\text { the foot } \\
\text { level(m) }\end{array}$} & \multirow{3}{*}{$\begin{array}{l}\text { Occupant } \\
\text { distribution }\end{array}$} & \multirow{3}{*}{$\begin{array}{l}\text { Pole } \\
\text { No. }\end{array}$} & \multicolumn{6}{|c|}{ Thermocouple height from the foot level(m) } \\
\hline & & & & 0 & 0.4 & 0.8 & 1.1 & 1.4 & 1.8 \\
\hline & & & & \multicolumn{6}{|c|}{ Air temperature $\left({ }^{\circ} \mathrm{C}\right)$} \\
\hline \multirow{3}{*}{$\begin{array}{c}\text { square air } \\
\text { duct }\end{array}$} & \multirow{3}{*}{$\begin{array}{c}\text { supply } \\
\text { terminal } \\
\text { height } 0.1 \mathrm{~h} \\
\text { above the } \\
\text { foot level }\end{array}$} & $1^{\text {st }}$ O.D. & $\begin{array}{l}\text { Pole1 } \\
\text { Pole2 } \\
\text { Pole3 }\end{array}$ & $\begin{array}{l}23.5 \\
23.5 \\
23.5\end{array}$ & $\begin{array}{l}23.4 \\
24.2 \\
24.1\end{array}$ & $\begin{array}{l}24.6 \\
24.9 \\
25.5\end{array}$ & $\begin{array}{l}25.3 \\
25.1 \\
25.6\end{array}$ & $\begin{array}{l}26.1 \\
25.7 \\
26.1\end{array}$ & $\begin{array}{l}26.3 \\
26.2 \\
26.3\end{array}$ \\
\hline & & $2^{\text {nd }}$ O.D. & $\begin{array}{l}\text { Pole1 } \\
\text { Pole2 } \\
\text { Pole3 } \\
\end{array}$ & $\begin{array}{l}22.1 \\
22.1 \\
22.1 \\
\end{array}$ & $\begin{array}{l}23.5 \\
23.5 \\
24.4 \\
\end{array}$ & $\begin{array}{l}23.6 \\
23.9 \\
24.6 \\
\end{array}$ & $\begin{array}{c}24.1 \\
24.1 \\
25 \\
\end{array}$ & $\begin{array}{l}24.5 \\
25.3 \\
25.1 \\
\end{array}$ & $\begin{array}{c}24.9 \\
26.1 \\
26 \\
\end{array}$ \\
\hline & & $3^{\text {rd }}$ O.D. & $\begin{array}{l}\text { Pole1 } \\
\text { Pole2 } \\
\text { Pole3 }\end{array}$ & $\begin{array}{l}24.9 \\
24.9 \\
24.9\end{array}$ & $\begin{array}{l}22.7 \\
24.5 \\
23.9\end{array}$ & $\begin{array}{l}24.6 \\
24.9 \\
24.5\end{array}$ & $\begin{array}{l}25.8 \\
25.1 \\
24.9\end{array}$ & $\begin{array}{c}26 \\
26.6 \\
25\end{array}$ & $\begin{array}{l}26.5 \\
26.3 \\
25.6\end{array}$ \\
\hline
\end{tabular}




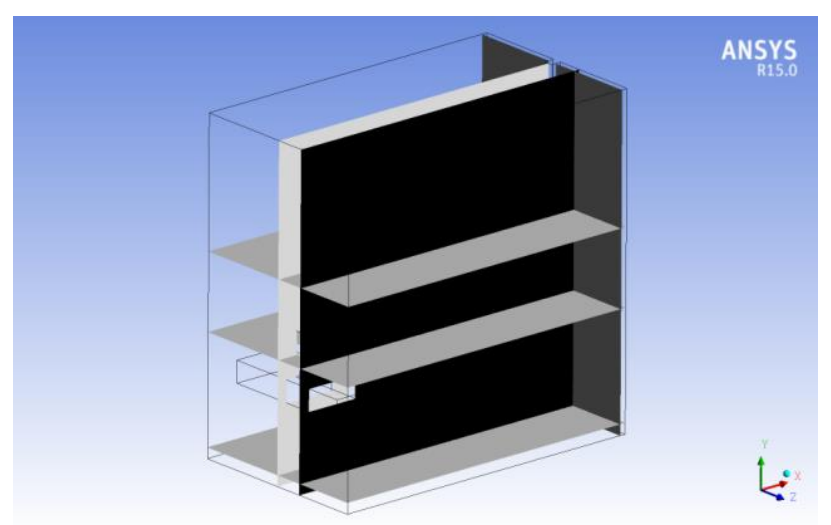

Figure (7): The schematic geometry of the room is stating for plot planes

Table4. Locations for each plane

\begin{tabular}{|c|c|c|c|}
\hline No. & $\begin{array}{c}\text { Title of } \\
\text { plane }\end{array}$ & plane & $\begin{array}{c}\text { Location } \\
\mathrm{m}\end{array}$ \\
\hline 1 & Plane 1 & $\mathrm{ZX}$ & $\mathrm{Y}=1.1$ \\
2 & Plane 2 & $\mathrm{ZX}$ & $\mathrm{Y}=1.8$ \\
3 & Plane 3 & $\mathrm{XY}$ & $\mathrm{Z}=0.875$ \\
4 & Plane 4 & $\mathrm{ZY}$ & $\mathrm{X}=2.95$ \\
5 & Plane 5 & $\mathrm{XY}$ & $\mathrm{Z}=1.15$ \\
6 & Plane 6 & $\mathrm{XZ}$ & $\mathrm{Y}=0.1$ \\
\hline
\end{tabular}
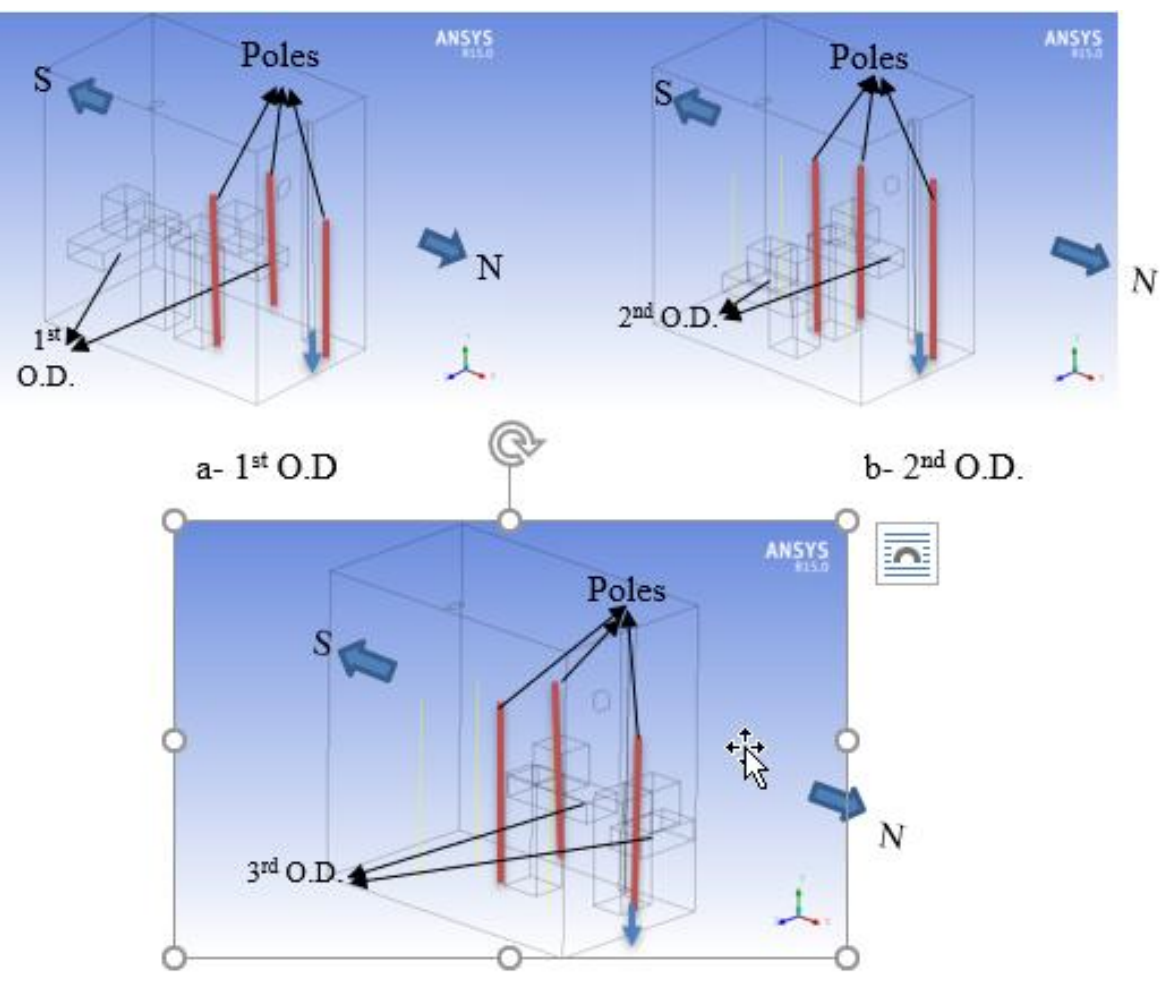

a- $3^{\text {rd }}$ O.D.

Figure (8): Configuration of tested room. 

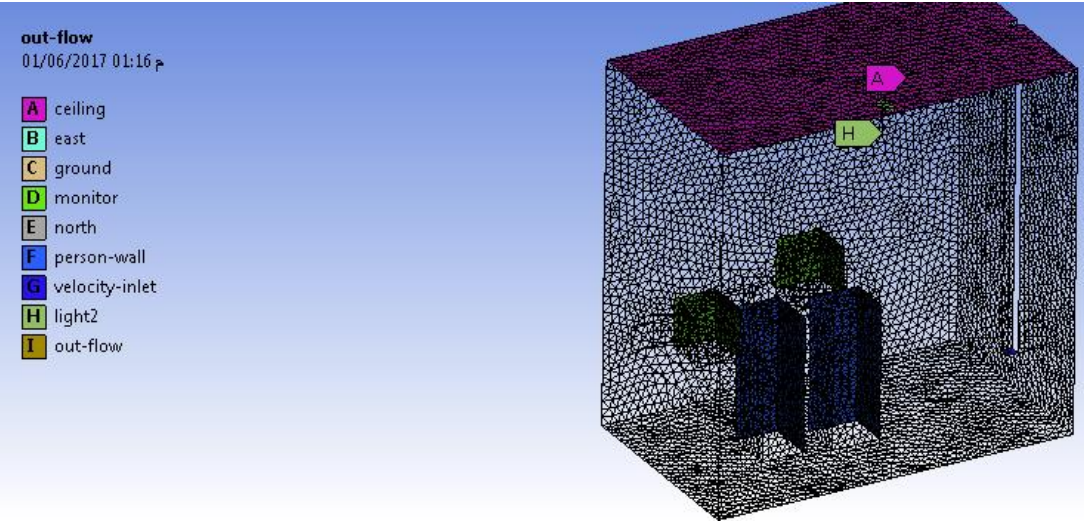

ANSYS

Figure (9): Mesh configurations with finer gird distributions near wall surfaces $1^{\text {st }}$ situation of occupant distribution.

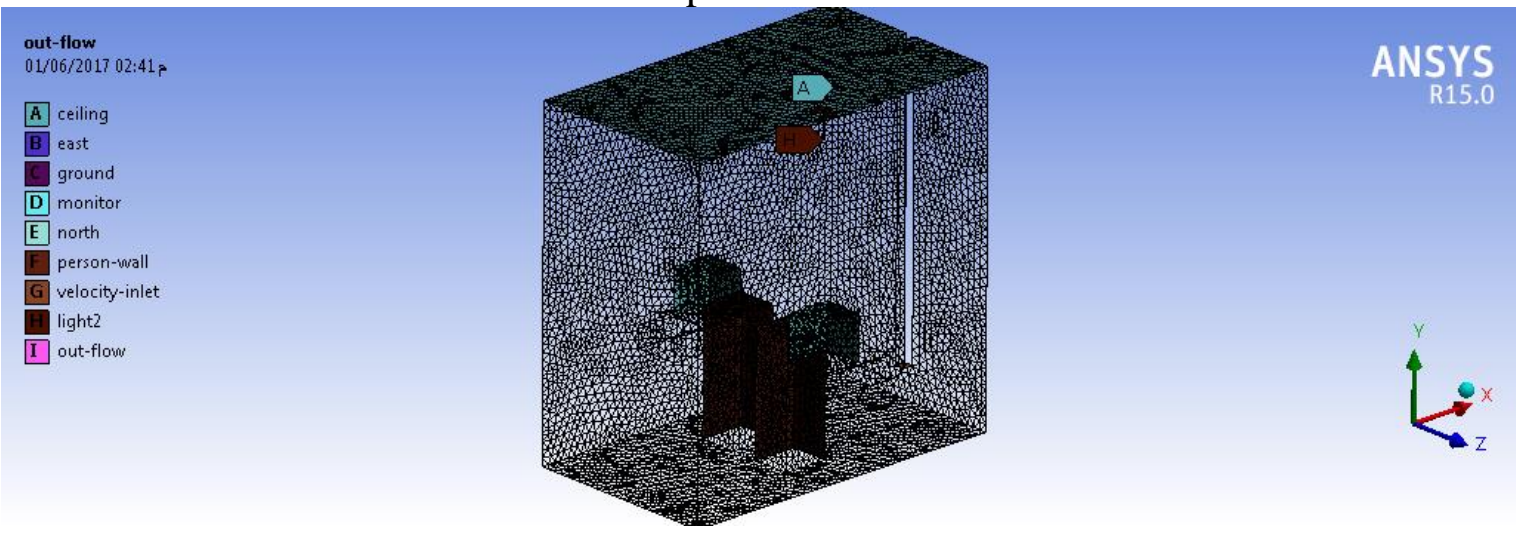

Figure (10): Mesh configurations with finer gird distributions near wall surfaces $2^{\text {nd }}$ situation of occupant distribution.

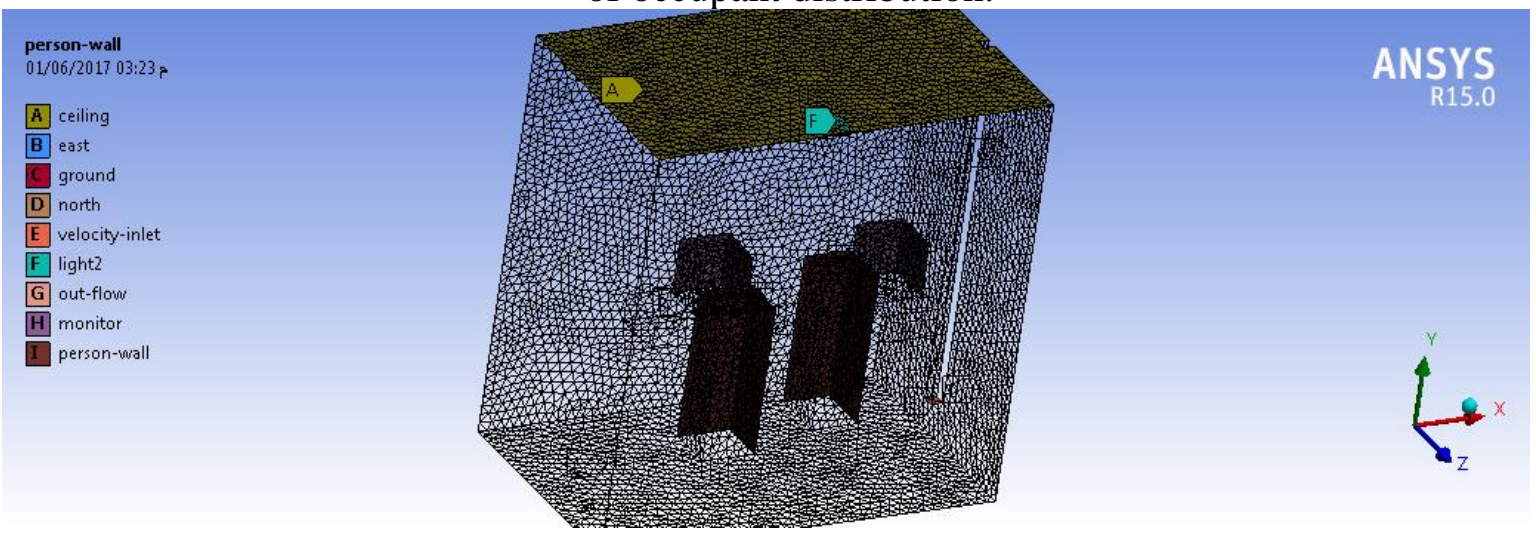

Figure (11): Mesh configurations with finer gird distributions near wall surfaces $3^{\text {rd }}$ situation of occupant distribution.

Table 5. Numerical values of ADPI, effectiveness temperature for air temperature.

\begin{tabular}{|c|ccc|}
\hline Type of supply air duct & \multicolumn{3}{|c|}{ Square cross sectional area } \\
\hline Distance from the foot level & \multicolumn{3}{|c|}{$0.1 \mathrm{~h}$} \\
\hline Occupant distribution & $1^{\text {st }}$ O.D. & $2^{\text {nd }}$ O.D. & $3^{\text {rd }}$ O.D. \\
\hline ADPI \% & 0.69 & 0.7 & $0 . .4$ \\
\hline Effectiveness & 0.91 & 1.027 & 0.94 \\
\hline
\end{tabular}




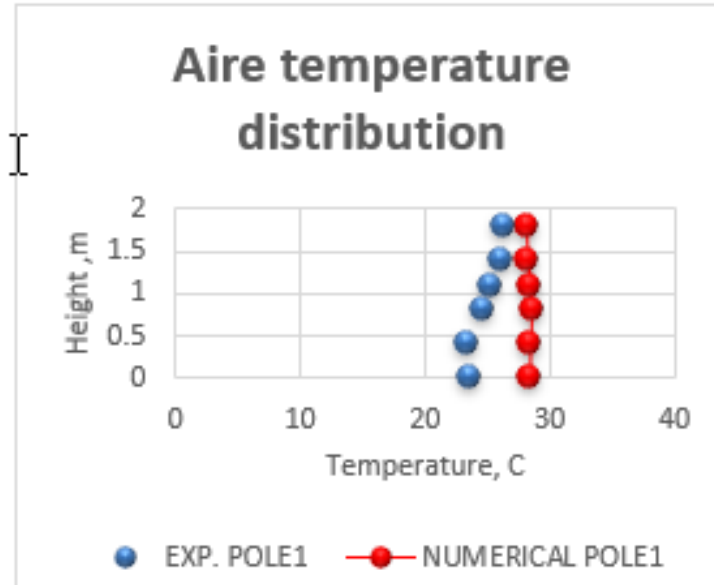

Figure (17): Comparison between predicted and experimental results, $1^{\text {st }}$ O.D.

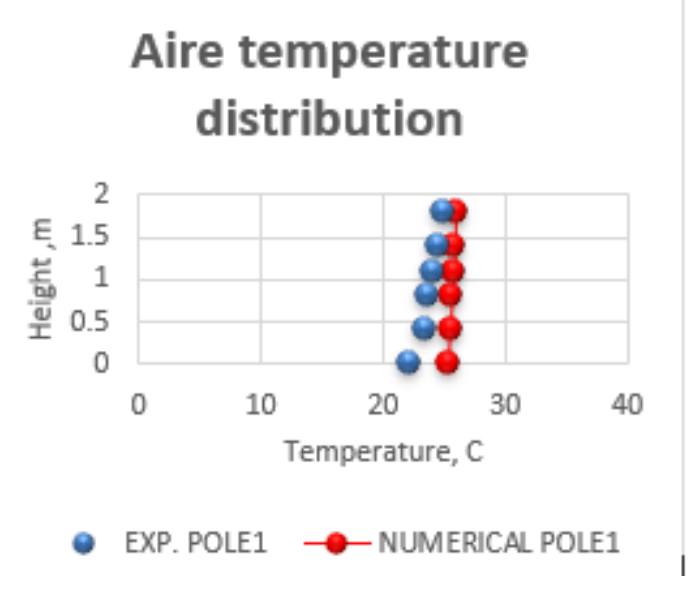

Figure (16): Comparison between predicted and experimental results, $2^{\text {nd }}$ O.D.

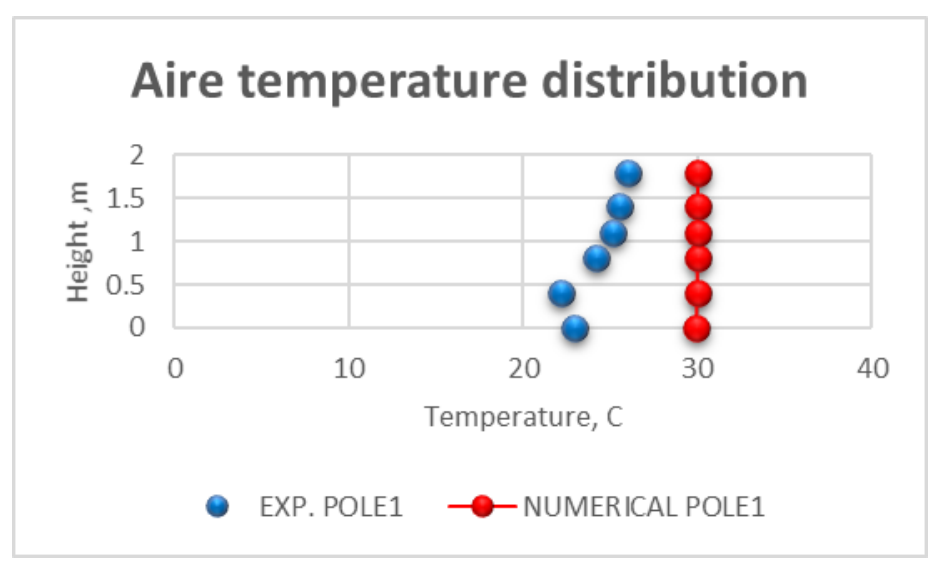

Figure (17): Comparison between predicted and experimental results, $3^{\text {rd }}$ O.D.

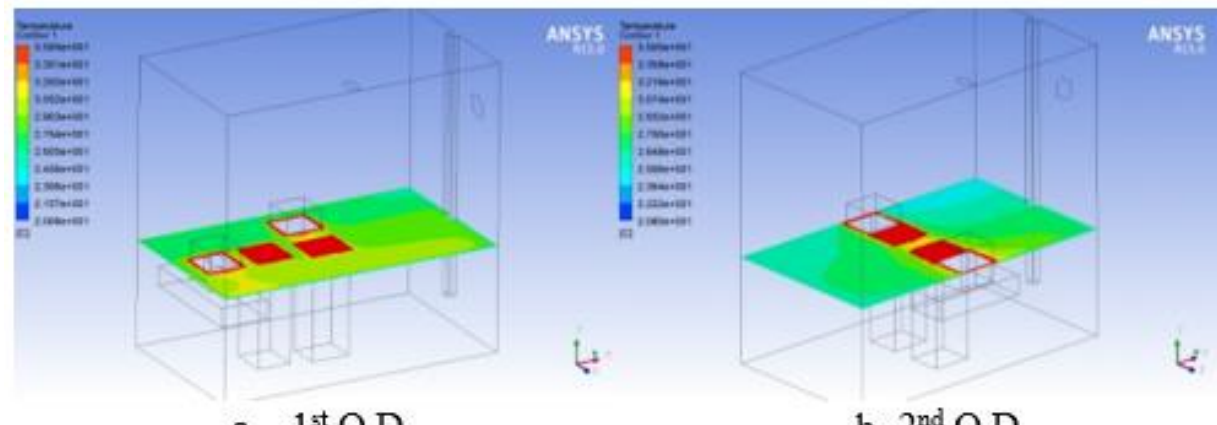

a- $1^{\text {st }}$ O.D

b- $2^{\text {nd }}$ O.D.

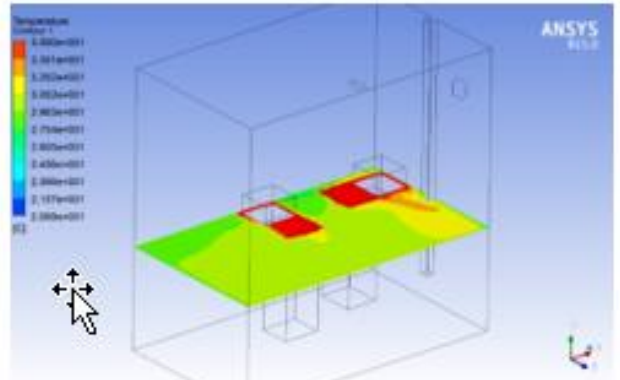

b- $3^{\text {rd }}$ O.D.

Figure (18): Temperature contour at $1.1 \mathrm{~m}$ (breathing zone) over the floor level for the impinging jet ventilation at plane- 1 . 


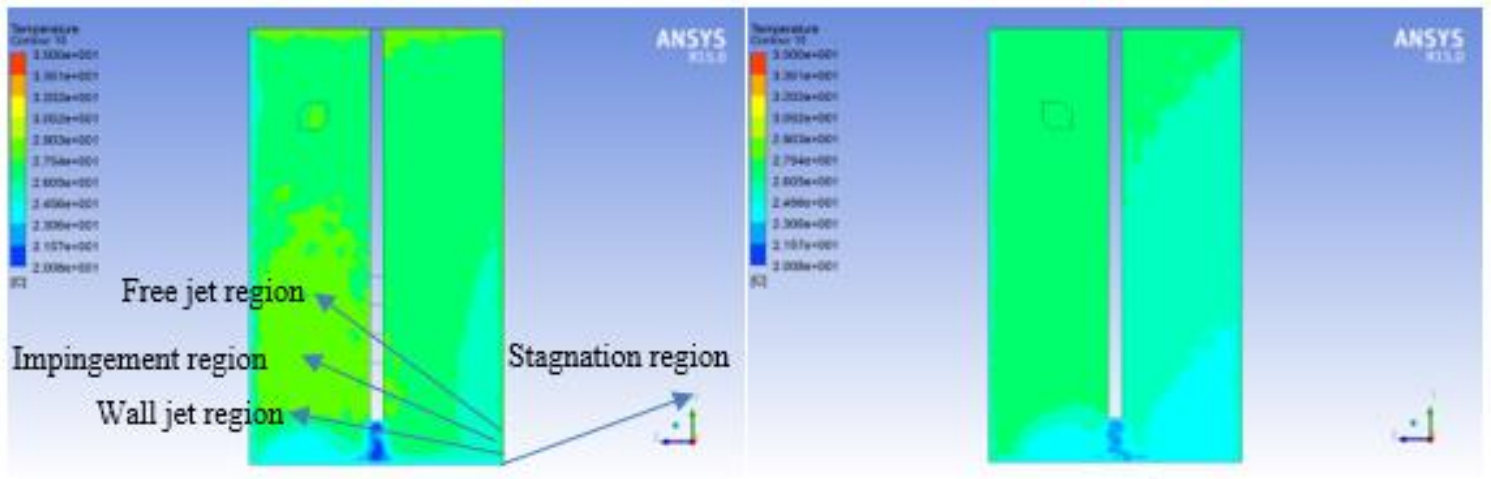

a-min $1^{\text {st }}$ O.D.

b- $2^{\text {nd }}$ O.D

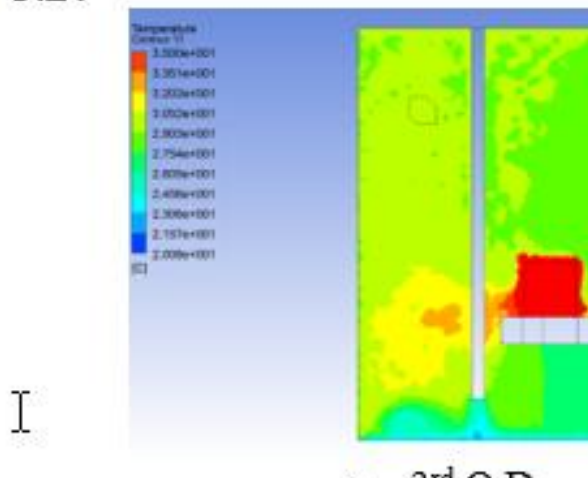

ANSYS

a- $3^{\text {rd }}$ O.D.

Figure (19): Temperature contour at plane-4 for the impinging jet ventilation

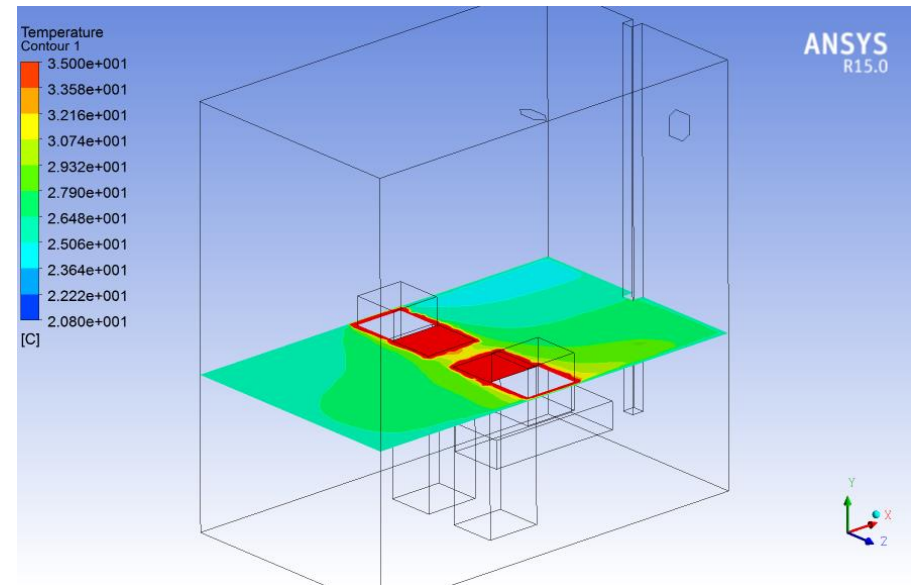

Figure (20): Temperature contour at $1.1 \mathrm{~m}$ (breathing zone) above the floor level by using impinging jet ventilation at plane- $1,2^{\text {nd }}$ situation. 


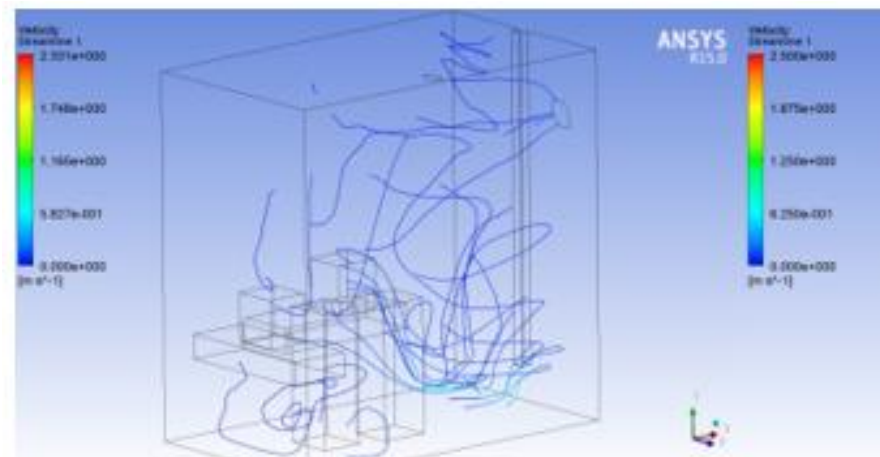

a- $1^{\text {st }}$ O.D.

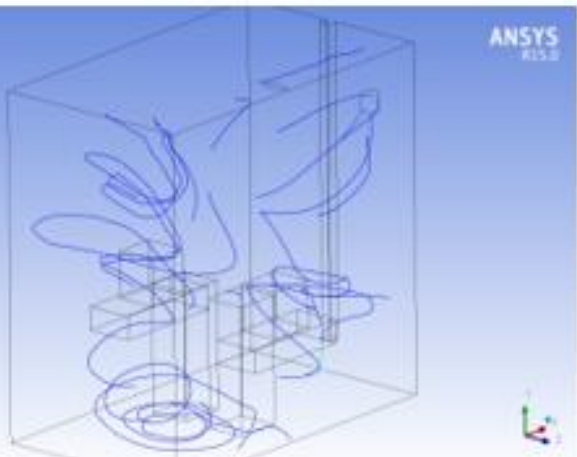

b- $2^{\text {nd }}$ O.D.

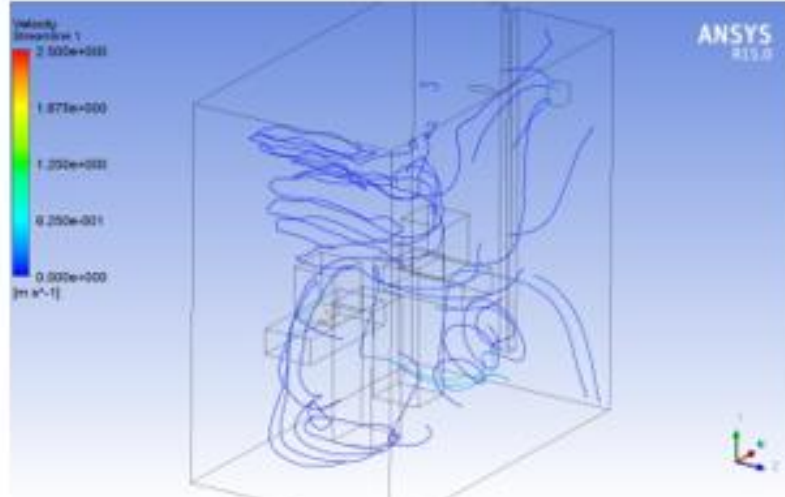

a- $3^{\text {rd }}$ O.D.

Figure (21): The computed streamlines for IJV perspective view.
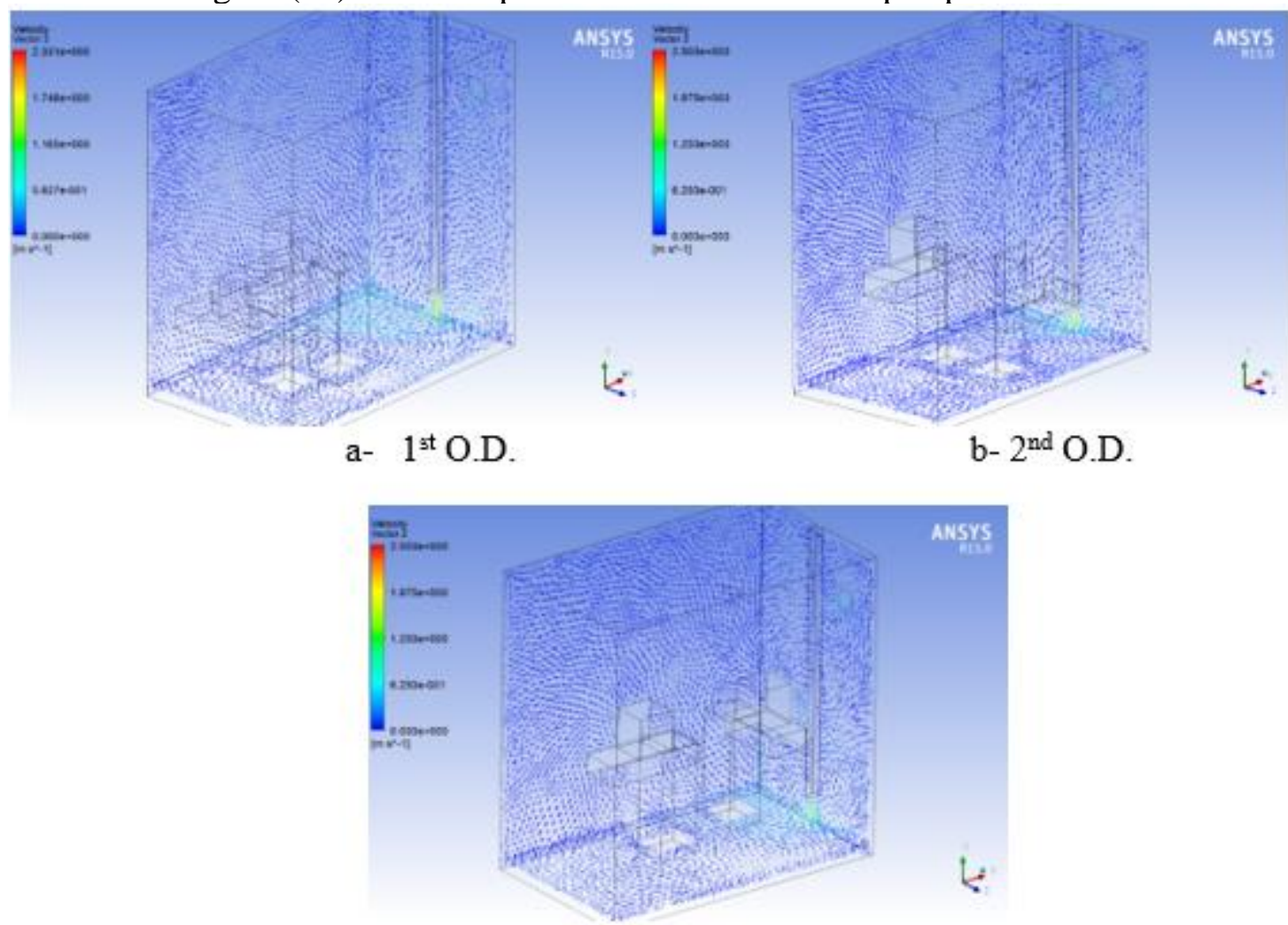

T

$$
\text { c- } 3^{\text {rd }} \text { O.D. }
$$

Figure (22): Plot the projected velocity vectors on the surfaces 0.05 meters from the entrance wall, side wall and floor. 


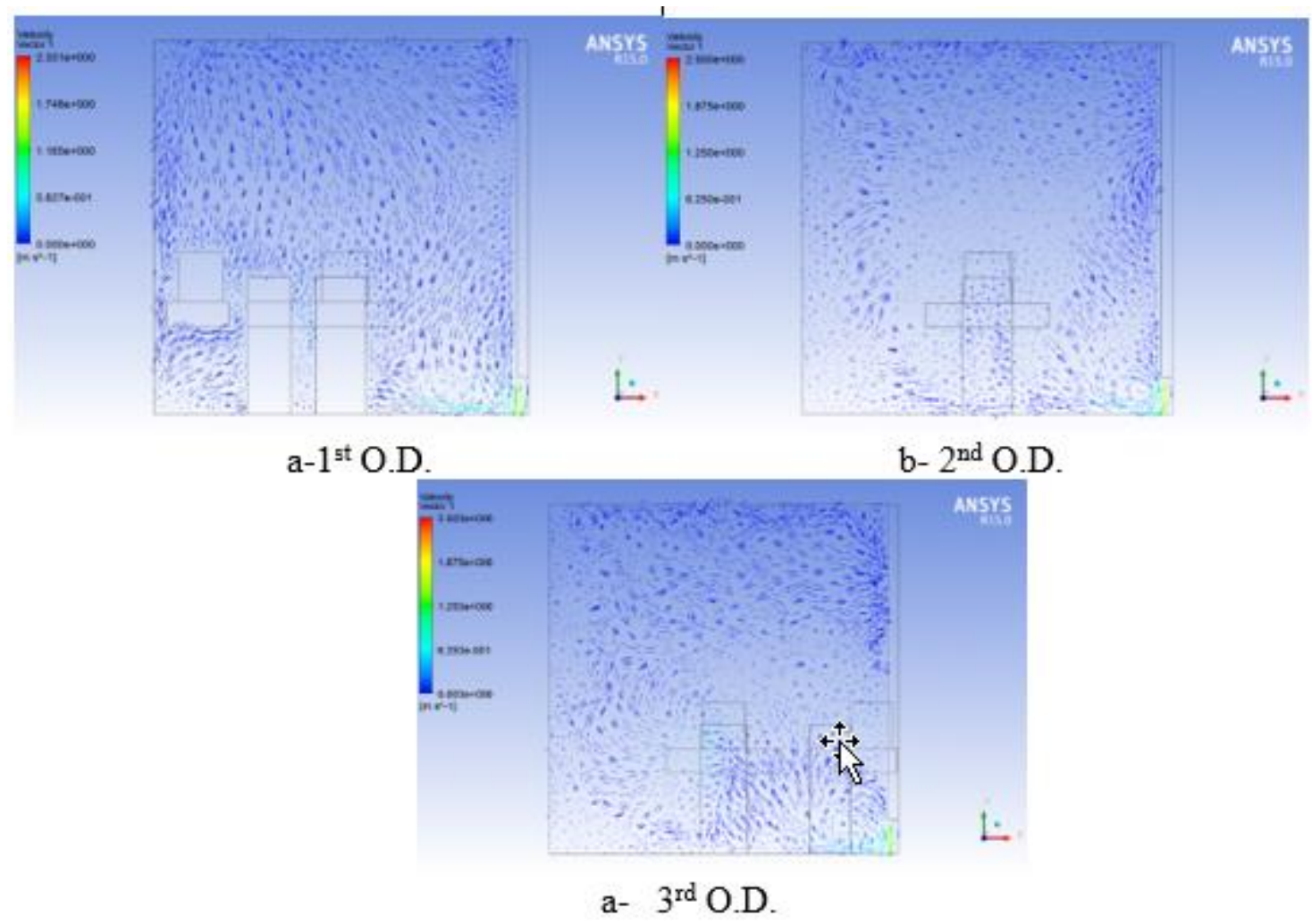

Figure (23): The predicted velocity vector plot at plane-3.

\section{REFERENCES:}

ASHRAE. Standard 55-2004, Thermal environmental conditions for human occupancy, Atlanta, GA: American Society for Heating, Refrigerating and Air Conditioning Engineers, 2004.

Beltaos S, Rajaratnam N. Plane turbulent impinging jets. Journal of Hydraulic Research; 11:29-59, 1973.

Chen, Q. \& Glicksman, L. System performance evaluation and design guidelines for displacement ventilation. Atlanta, GA: American Society of Heating, Refrigerating, and Air-conditioning Engineers, Inc, 2003.

Chen, Q., Glicksman, L.R., Yuan, X., Hu, S., \& Yang, X., Final report for ASHRAE RP-949: Performance evaluation and development of design guidelines for displacement ventilation. Cambridge, MA: Department of Architecture, Massachusetts Institute of Technology, 1999.

FLUENT Inc. FLUENT 6.3.26 user's guide, 2006.

H. B. Awbi, Ventilation of Buildings, Spon Press, second edition, 2003.

Huijuan Chen, Bahram Moshfegh a,b, Mathias Cehlina, "Computational investigation on the factors influencing thermal comfort for impinging jet ventilation", University of Gävle, 80176 Gävle, Sweden, 2013. 
Huijuan Chen, Experimental and numerical investigations of a ventilation strategy impinging jet ventilation for an, office environment, Msc.thesis, Linköping University, 2014.

H.J. Chen , B. Moshfegh , M. Cehlin, Numerical investigation of the flow behavior of an isothermal impinging jet in a room, University of Gävle, 80176 Gävle, Sweden, 2011.

Iraqi cooling code, 2012.

Lee K, Xue GQ, JIANG Z, Chen QY. Thermal environment in indoor spaces with under-floor air distribution systems: 1. Impact of design parameters. HVAC\&R Research 2012;

Samira Haghshenaskashani1, Behrang Sajadi1, Mathias Cehlin², Multi-objective optimization of impinging jet ventilation systems: Taguchi-based CFD method, (1)School of Mechanical Engineering, College of Engineering, University of Tehran, Tehran, Iran, (2)Department of Building, Energy and Environmental Engineering, Faculty of Engineering and Sustainable Development, University of Gävle, Gävle, Sweden,2018.

T. Karimipanah, H.B. Awbi Theoretical and experimental investigation of impinging jet ventilation and comparison with wall displacement ventilation, The University of Reading,reading RG6 6AW, UK, 2001.

Varodoumpun J, Navvab M. The impact of terminal configuration in impinging jet ventilation room. Sendai, Japan. In: The 6th international conference on indoor air quality, ventilation \& energy conservation in buildings IAQVEC2007.

Varodompun J, Navvab M. HVAC ventilation strategies: the contribution for thermal comfort, energy efficiency, and indoor air quality. Journal of Green Building 2007. 